\title{
Evaluation of Cytotoxic Activity in Ethanolic Extract of Cucumis melo (L). fruit ${ }^{\dagger}$
}

\author{
Vidya R. ${ }^{1, *}$, Kalaivani K. ${ }^{1}$ \\ 1 Department of Biochemistry, Vels Institute of Science, Technology \& Advanced Studies, Chennai, Tamilnadu-600117, \\ India \\ * Correspondence: vidyabiochem@gmail.com; \\ $\dagger$ Presented at International e-Conference on Bioengineering for Health and Environment (ICBHE 2020)
}

Received: 5.07.2020; Revised: 10.07.2020; Accepted: 12.07.2020; Published: 15.07.2020

\begin{abstract}
Cytotoxicity is the quality of being toxic to cells, and in vitro cytotoxicity testing procedures reduce the use of laboratory animals. The present study was designed to investigate the cytotoxic activity of the Cucumis melo (L) fruit against HepG2 cell lines. To prepare the extract, fresh pulps of Cucumis melo fruit was chopped into pieces and dried at room temperature for 24 hours. $10 \mathrm{~g}$ of the dried fruit powder was successively extracted with $100 \mathrm{ml}$ of ethanol using Soxhlet apparatus and filtered through Whatman No 1 filter paper. The cytotoxic activity for cancer cell lines was evaluated by MTT assay. The in vitro cytotoxicity of different concentrations $(18.75-300 \mu \mathrm{g} / \mathrm{mL})$ of the ethanolic extract of Cucumis melo fruit was evaluated by the MTT assay. The IC50 value is measured by the concentration of extract, causing 50\% growth inhibition of cancer cells. The results indicated that the cytotoxic effect of the ethanolic extract of Cucumis melo fruit against HepG2 cells is dose-dependent. At low concentrations, the extract was found to be less toxic towards the HepG2 cells, whereas, at higher concentrations, the toxicity was increased. The concentration at $201.5 \mu \mathrm{g} / \mathrm{ml}$ was found to be an effective dose because, at this concentration, it exhibited $50 \%$ cytotoxicity against HepG2 cells. This work revealed the potentials of ethanolic extract of Cucumis melo fruit as a cytotoxic agent against liver cancer cell lines. The plant can be further screened against various diseases using toxicity models in order to find out its unexplored efficacy.
\end{abstract}

Keywords: Cytotoxicity; Cucumis melo (L); Inhibition Concentration (IC 50); HepG2 cell lines;

MTT.

(C) 2020 by the authors. This article is an open-access article distributed under the terms and conditions of the Creative Commons Attribution (CC BY) license (https://creativecommons.org/licenses/by/4.0/).

\section{Funding}

This research received no external funding.

\section{Acknowledgments}

This research has no acknowledgment.

\section{Conflicts of Interest}

The authors declare no conflict of interest. 